182、注腸X線検査における表面型大腸腫瘤の描出能について Detectability of Superficial Type Tumor of

Large Intestine on Barium Enema Examination.

埼玉県立がんセンター・放射線診断部

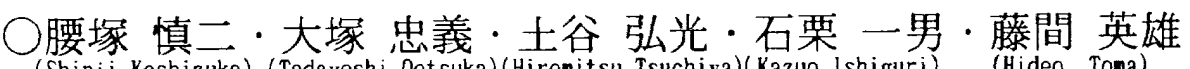
(Shinji Koshizuka) (Tadayoshi Ootsuka)(Hironitsu Tsuchiya)(Kazuo Ishiguri) (Hideo Tona)

\title{
【目的 】
}

注腸X線検査において描出が困難とされている表面型大腸循瘤について、特に前処置状態が良好でも描出が得られな かった畽瘤について検討したので報告する。

【 対象・検討項目 】

対象は、大腸内視鏡検査にて表面型大腸腫瘁と診断され、大腸内視鏡検查前に注腸X線検査を施行した 117 病変のう

ち、前処置の状態が良好であった 98 病変とした。尚、同一占拠部位に多数の病变を認める症例については除外した。 検討項目は、表面型大晹腫瘤の占拠部位、大きさ、立ち上がりの 3 項目とした。

【検討方法 】

腫瘦の立ち上がり、注腸X線検查にて描出陰性となった腫瘤の大きさについては、大腸内視鏡所見を retorospective に檢討し、腫瘤の占拠部位、大きさについては、注腸所見を retorospectiveに検討した。

【前処置状態の評価】

前処置状態の評価として、固形残渣量、 バリウム付着性を別々に、評価基準フィ ルムを用いて 4 段階評価（優秀、良好、 不良、不可) し、今回対象とした前処置 良好とは2 項目がともに評価良好以上の 症例とした。

\section{【結果 】}

表面型大腸腄痹 98 病変のうち X線描 出陽性は、86例 $87.8 \%$ であった。

1. 占拠部位別の描出能を表 1 に示す。 占拠部位別では、直晹で描出率が $76.9 \%$ で最も低かった。

2. 大きさ別の描出能を表 2 に示す。 大きさ別では、腫痹径が $5 \mathrm{~mm}$ 以下で描出 率 $68.2 \%$ となり、最も低い結果となった。

3. 立ち上がりからみた描出能では、立 ち上がりが急峻なるのに比べ、なだらか なものが描出率は低かった。

\section{【考察】}

注腸 X線検査における表面型大腸腫瘤 98 病変について検討した結果、前処置良 好でのX線描出陽性は 86 例 $87.8 \%$ であっ た。また前処置状態が良好でも描出が得

\section{表 1 表面型腫㿔における占居部位別描出能}

\begin{tabular}{|c|c|c|}
\hline & 描出隔性（\%） & 描出陰性（\%） \\
\hline 亩晹 & $5(83.3)$ & 1 (16.7) \\
\hline 上行桔晹 & 14 (93.3) & $(6.7)$ \\
\hline 横行站晹 & $22 \quad(88.0)$ & (12.0) \\
\hline 下行結䦨 & $15(88.2)$ & (11.8) \\
\hline$S$ 状轺腸 & $20 \quad(90.9)$ & $(9.1)$ \\
\hline 直腥 & $10 \quad(76.9)$ & $(23.1)$ \\
\hline Total & $86 \quad(87.8)$ & $12(12.2)$ \\
\hline
\end{tabular}

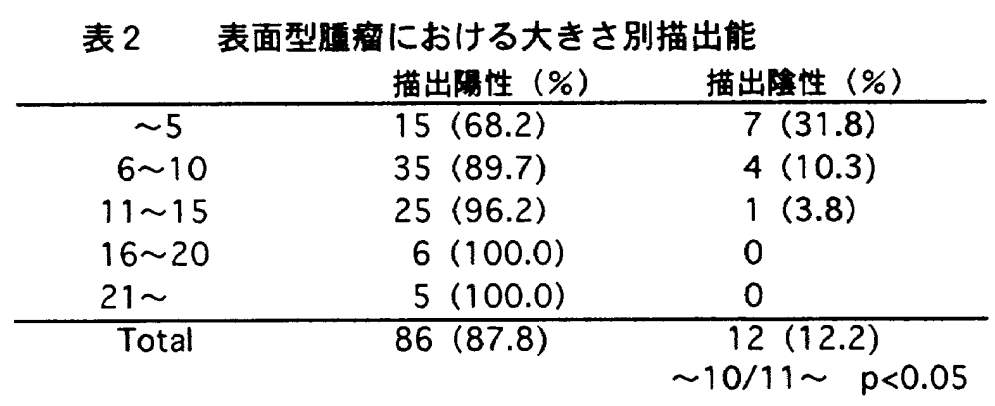

表 3 表面型㯖度における立ち上がりと描出能

\begin{tabular}{|c|c|c|}
\hline & 描出阳性（\%） & 描出㓌性（\%) \\
\hline 鋭 & $24(100.0)$ & 0 \\
\hline 钝 & $62(83.8)$ & $12(16.2)$ \\
\hline Total & $86(87.8)$ & $12(12.2)$ \\
\hline
\end{tabular}
られなかった症例は 12 例 $12.2 \%$ みらた。 描出されなかった主な理由として腫㢞径の小さなもの、立ち上がりがなだらかなものがあげられた。特に、立ち上がり については、急峻なものが描出率100\%であったのに対して、なだらかなものは83.8\%となった。また描出陰性例をみ ると立ち上がりがなだらかで腫瘦径の小さな病変であった。今後これらの病変を効率よく描出するためには、撮影する タイミングや薄層法、生迫法などの撮影法の工夫が必要と考えられた。 